\title{
Long-term changes in macrozoobenthic abundance on the tidal flats of the western part of the Dutch Wadden Sea*
}

\author{
J. J. Beukema \\ Netherlands Institute for Sea Research; P.O. Box 59, 1790 AB Den Burg, The Netherlands
}

\begin{abstract}
For 20 years (1969-1988), larger bottom animals have been sampled quantitatively once or twice annually at 15 stations scattered over Balgzand $\left(\mathrm{a} 50 \mathrm{~km}^{2}\right.$ tidal flat area in the westernmost part of the Dutch Wadden Sea). In 29 species, numbers were sufficiently high to allow a statistical evaluation of the fluctuation patterns of their annual densities. The results revealed two main trends: (1) a sensitivity to low winter temperatures in 12 species, causing low densities in these species immediately after a severe winter (1979, 1985, 1986 and 1987) and relatively high densities during a period with some mild winters in succession (1973-1975); (2) an upward long-term trend in 11 (other) species, causing upward trends (viz. roughly a doubling) of total macrozoobenthic biomass and production over the 20-year period of observation, probably as a consequence of increasing eutrophication. By far the major part of the species thus exhibited either of these two patterns, causing total biomass and species number to be governed largely by the above two trends. Results of less frequent sampling (once per 5 or 10 years) of 26 transects scattered over the $\sim 500 \mathrm{~km}^{2}$ of tidal flats of the whole western half of the Dutch Wadden Sea showed that the two trends also represent the changes occurring in a much larger area. Some local departures from the general patterns are discussed and related to specific causes.
\end{abstract}

\section{INTRODUCTION}

Numbers in populations of living organisms usually fluctuate. Fluctuations in densities of small animals are often violent. Fortunately, in many cases there is some system in such fluctuations: either consistent long-term trends or cycle-like patterns may be present. Moreover, identical patterns may exist simultaneously in different areas and in different species. Such parallel fluctuations can be revealed by long-term monitoring studies executed over vast areas, as has been shown for the macrozoobenthos of the Wadden Sea by Beukema \& Essink (1986).

If several species show parallel patterns of fluctuation, a common cause will have affected their densities in the same way, either by improving or by deteriorating their conditions of life. If such common patterns occur over vast areas, these causes will have operated on a large geographic scale and this may give a clue to their character (e.g. a climatic change). If, in a distinct local subarea, the pattern deviates from the general fluctuation pattern in one or more species, a strictly local cause will have been operative

\footnotetext{
- Presented at the VI International Wadden Sea Symposium (Biologische Anstalt Helgoland, Wattenmeerstation Sylt, D-2282 List, FRG, 1-4 November 1988)
} 
(an example of a waste discharge is shown by Essink \& Beukema, 1986). A locally operating factor of this kind will have a disturbance character and may or may not be related to a man-made interference (such as a poisonous discharge). The evidence of a causal relationship between a known environmental change and an observed change in the density of a population is stronger if it can be shown that this population change did not occur in other areas and differed significantly from the general trends. Thus, a largescale and long-term monitoring programme provides not only general base-line information on long-term trends, but can also furnish material to prove in specific cases that a local disturbance has indeed caused an observed change in numbers of living organisms. Internationally coordinated programmes will be needed to cover sufficiently large areas with sampling programmes executed in a uniform way at widely different locations.

Results of a 20-year monitoring study of the macrozoobenthos at 15 tidal-flat stations located in a restricted area (Balgzand) will be presented to show that parallel fluctuation patterns (common to several species and occurring at several stations) do exist. A comparison of these Balgzand patterns with changes in densities observed in other (distant) areas shows that these patterns may occur over vast areas. Comparable results are available of a less frequent sampling programme of the tidal flats of the western half of the Dutch Wadden Sea (by the author) and of regular monitoring programmes in a restricted tidal-flat area in the eastern part of the Dutch Wadden Sea (by Essink, see Essink \& Beukema, 1986) and in the German (Dörjes et al., 1986; Rhode, 1986) and Danish (Brinch Madsen, 1984) Wadden Sea. These programmes are being coordinated in the European Community programme COST-647.

\section{MATERIAL AND METHODS}

At the intensively studied Balgzand (Fig. 1), 15 permanent stations (marked by iron poles) have been sampled once (in or around March) or twice (also in August-September) annually ever since 1969. Details on the location of the stations, the local environmental conditions, the methods applied and the faunal distribution can be found in earlier papers (Beukema, 1974, 1988; Beukema et al., 1983). In brief, at each station (mostly a $1-\mathrm{km}$ transect) 18 to (mostly) 50 core samples (together 0.45 to $1.8 \mathrm{~m}^{2}$, mostly $0.9 \mathrm{~m}^{2}$ ) were sieved in the field ( $1 \mathrm{~mm}$ mesh) and sorted alive in the laboratory. For each species, numbers were counted (and expressed per $\mathrm{m}^{2}$ ), and ash-free dry weight (AFDW) values determined by drying to constant weight and subsequent ashing.

Along the 26 occasionally sampled transects, scattered over the $\sim 500 \mathrm{~km}^{2}$ of tidal flats of the western half of the Dutch Wadden Sea (Fig. 1), 25 samples of $1.9 \mathrm{dm}^{2}$ each were taken and treated in the same way as the Balgzand samples. This additional sampling programme was carried out in the summer or autumn of 1971 and 1972, 1977 and 1987. The correlations between the various fluctuation patterns and between the annual numbers and year number were evaluated by Spearman's rank correlation test. Differences between mean values were evaluated with a non-parametric test too, viz. the Wilcoxon matched-pairs signed-ranks test. In some cases, standard errors are shown to give an impression of the high scatter of the data. 


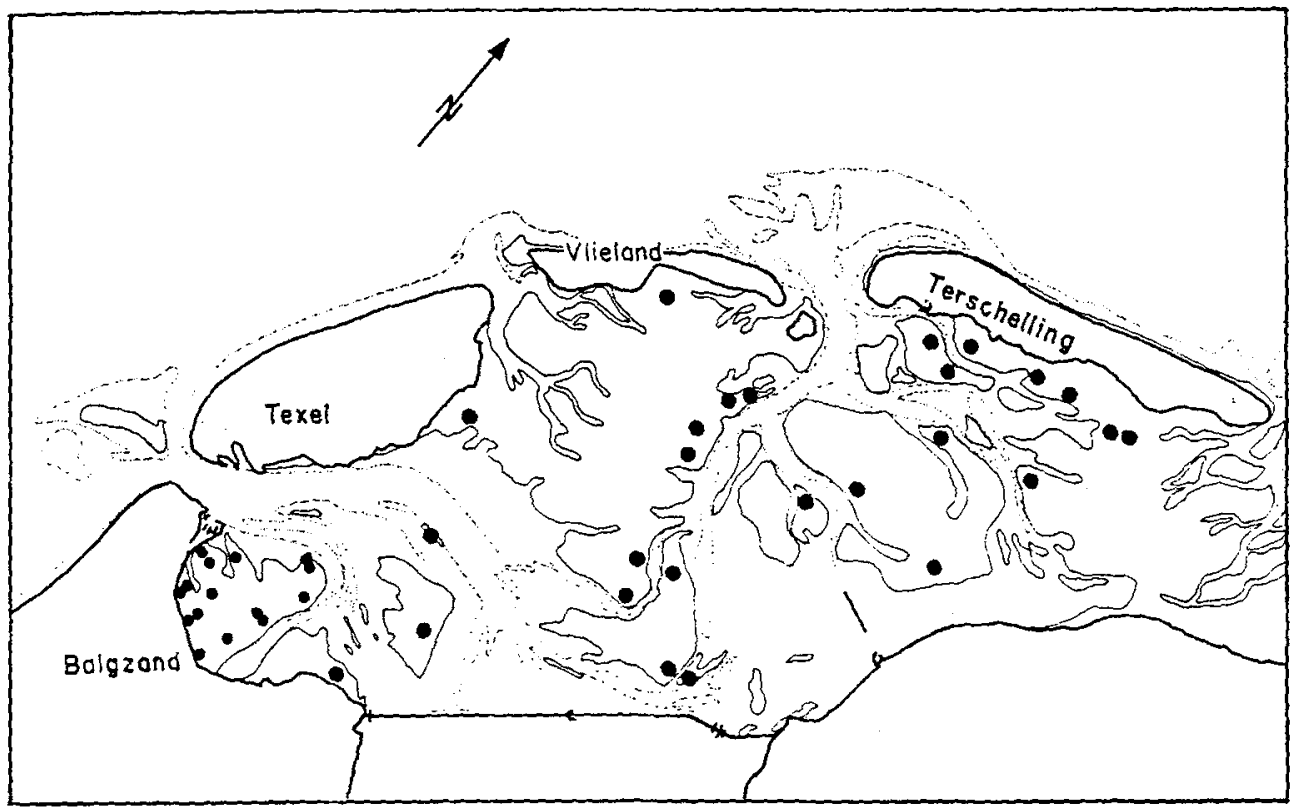

Fig. 1. Map of the western half of the Dutch Wadden Sea, showing contours of tidal flats and locations of the sampling stations (15 at Balgzand and 26 on other tidal flats)

\section{RESULTS AND DISCUSSION}

\section{Long-term trends}

At Balgzand, 29 species were sufficiently numerous (i.e. more than half of the annual figures were above 0 ) at one or more stations to evaluate the changes in their abundance. In 11 out of these 29 species (listed in Table 1: the top group), the mean annual densities (as observed in March) increased significantly (Spearman's test with $\mathrm{n}=20$ ) over the 1969-1988 period. Increasing species were much more numerous than decreasing ones, as only 2 out of the total of 29 species showed a significant (0.05-level) decrease over this period (both were sensitive to low winter temperatures, see below).

Among the increasing species, several contributed high amounts to total macrobenthic biomass. As a result, total biomass values at Balgzand increased significantly $(p<0.01$ ) over the 1969-1988 period and roughly doubled (Fig. 2a). The total number of species encountered at Balgzand fluctuated without a clear trend (Fig. 2b), but the number of species found per sampling station (corrected to $0.9 \mathrm{~m}^{2}$, if necessary) increased significantly ( $p<0.05$; Fig. $2 c$ ). This will have been caused by the higher numerical densities in the later years, increasing the likelihood of hitting a low-density species within the restricted area of $0.9 \mathrm{~m}^{2}$. The total number of species was less affected by higher densities, probably because the total area sampled ( 15 times the area per station) was large enough to catch at least one specimen of nearly all species present.

Similar changes were observed at the other tidal flats in the western half of the Dutch Wadden Sea (Fig. 2; Table 1): 

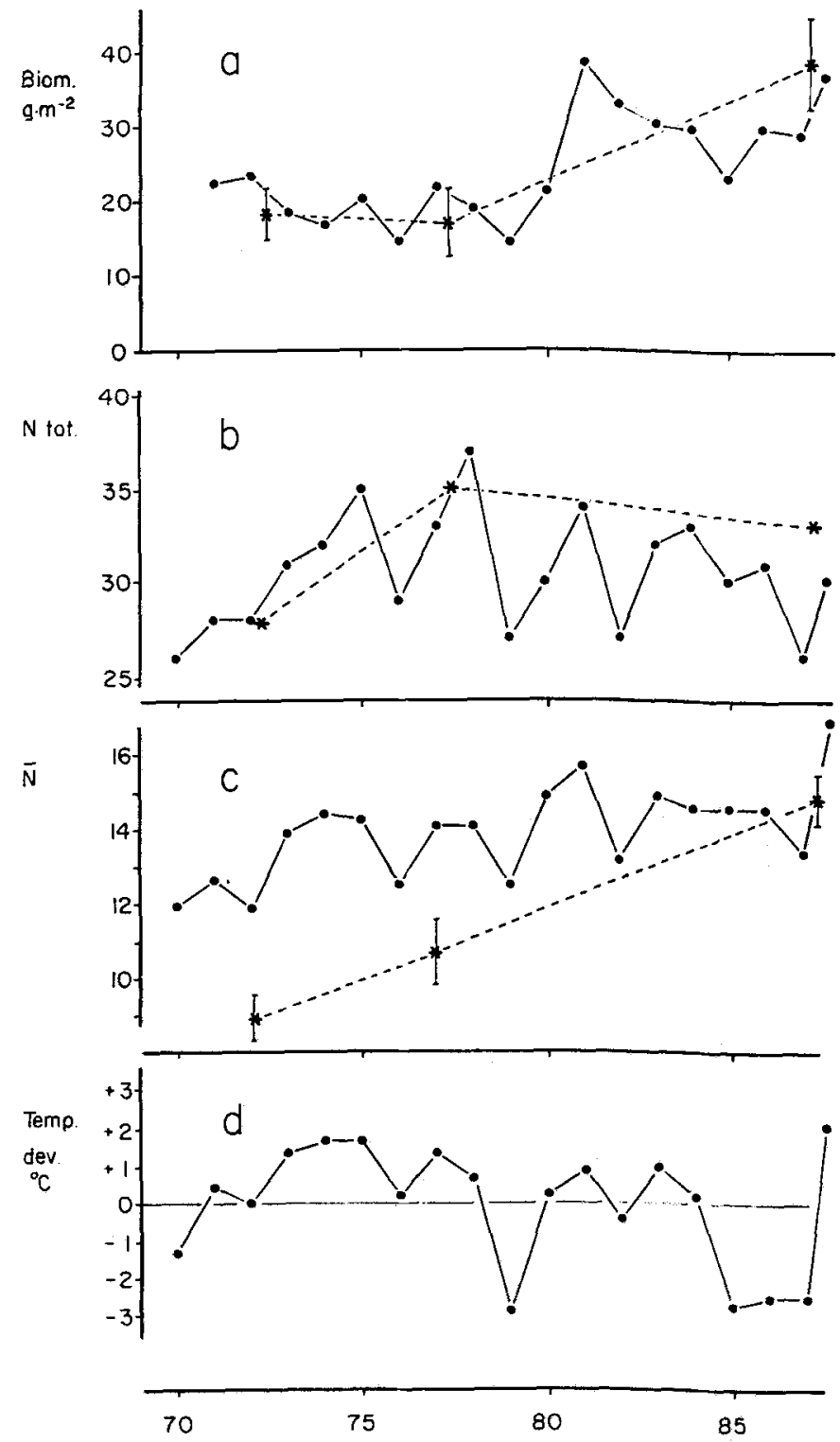

Fig. 2. Long-term trends in biomass and species richness of macrozoobenthos on tidal flats in the western half of the Dutch Wadden Sea. Annual data from March sampling at Balgzand (means of 15 stations, full points and solid lines). Less frequent data from 3 sampling programmes in summer or autumn of 1971-72, 1977 and 1987 on tidal flats outside Balgzand (means of 26 stations with 1 s.e., * and broken lines). (a) Mean biomass in $\mathrm{g}$ AFDW per $\mathrm{m}^{2}$. The increase at Balgzand is significant $(\mathrm{p}<0.01)$, as is the difference between the 1987 average and each of the other 2 means on the other tidal flats. (b) Total number of species found (at $13.5 \mathrm{~m}^{2}$ of Balgzand and $12 \mathrm{~m}^{2}$ of other tidal flats). (c) Mean number of species per sampling station $\left(0.9 \mathrm{~m}^{2}\right.$ at Balgzand and $0.45 \mathrm{~m}^{2}$ on other tidal flats): (d) Deviation (in ${ }^{\circ} \mathrm{C}$ ) of mean winter temperature (Dec-Febr) from long-term average (air temperatures at nearby weather station; data from KNMI, 1968-1988) 
Table 1. Changes in the abundance of 29 macrozoobenthic species in the western half of the Dutch Wadden Sea (except Balgzand). Numerical densities $\left(n \cdot m^{-2}\right)$ and biomass values $\left(g\right.$ AFDW $\cdot m^{-2}$ ) were estimated in summer or autumn of 1971-72, 1977 and 1987, and are given as means of observations at 26 tidal flat stations. The species are grouped according to their fluctuation type at Balgzand, March samples (see text). ${ }^{*}(<0.05)$ or ${ }^{*}(<0.01)$ between values denote statistical difference; asterisks placed after the 1987-value refer to the difference from the 1971-72-value (Wilcoxon's test with $\mathrm{n}=26$ )

\begin{tabular}{|c|c|c|c|c|c|c|}
\hline \multirow[t]{3}{*}{ Fluctuation type } & \multicolumn{6}{|c|}{ Abundance estimate } \\
\hline & \multicolumn{3}{|c|}{ Numerical density } & \multicolumn{3}{|c|}{ Biomass value } \\
\hline & $1971-72$ & 1977 & 1987 & $1971-72$ & 1977 & 1987 \\
\hline \multicolumn{7}{|l|}{ Increasing trend } \\
\hline Nereis diversicolor & 8 & $8^{* *}$ & $43^{* *}$ & 0.5 & $0.8^{*}$ & $2.2 * *$ \\
\hline Heteromastus filiformis & 21 & $13^{*}$ & $115^{*}$ & 0.3 & $0.1 * *$ & $1.2 \cdots$ \\
\hline Scoloplos armiger & 38 & $44^{* *}$ & $192^{* *}$ & 0.6 & $0.6^{*}$ & $1.0 *$ \\
\hline Eteone longa & 2 & $4^{*}$ & $11^{* *}$ & 0.0 & $0.0^{*}$ & $0.03^{*}$ \\
\hline Scolelepis foliosa & 0 & $0^{\cdots}$ & $3^{* *}$ & 0.0 & $0.0^{\cdots}$ & $0.1 \cdots$ \\
\hline Anaitides spp. & 1 & $4^{*}$ & $7^{* *}$ & 0.0 & $0.0^{*}$ & $0.02^{*}$ \\
\hline Arenicola marina & $11 *$ & $7^{*}$ & 16 & $4.6^{*}$ & $1.9^{\cdots}$ & 6.2 \\
\hline Macoma balthica & 27 & $32 *$ & $178^{* *}$ & 1.2 & $1.0^{*}$ & $5.1 \cdots$ \\
\hline Mytilus edulis & $1 *$ & 59 & $16^{*}$ & 0.8 & 4.0 & 0.9 \\
\hline Scrobicularia plana & 0 & 0 & 0 & 0.0 & 0.0 & 0.0 \\
\hline Littorina littorea & 0 & 0 & 0 & 0.0 & 0.0 & 0.0 \\
\hline \multicolumn{7}{|l|}{ Winter sensitive } \\
\hline Nephtys hombergii & $21^{\cdots}$ & 29 & 31 & 0.6 & 0.6 & 0.7 \\
\hline Lanice conchilega & $8^{*}$ & 71 & $53^{\cdots}$ & $0.4^{\circ}$ & 2.6 & 1.0 \\
\hline Magelona papillicornis & 2 & 1 & 1 & 0.0 & 0.0 & 0.0 \\
\hline Harmothoe lunulata & 0 & 3 & 0 & 0.0 & 0.0 & 0.0 \\
\hline Harmothoe cf. sarsi & 2 & $2 *$ & $6^{*}$ & 0.0 & $0.0^{\cdots}$ & $0.1^{\cdots}$ \\
\hline Nemerteans & 0 & 1 & 1 & 0.0 & 0.0 & 0.0 \\
\hline Cerastoderma edule & 9 & $14^{*}$ & $367^{\cdots}$ & 5.1 & 3.0 & 9.5 \\
\hline Mysella bidentata ++ & 0 & 1 & 0 & 0.0 & 0.0 & 0.0 \\
\hline Angulus tenuis ++ & $1 \cdots$ & $2 \cdots$ & 0 & $0.0^{\cdots}$ & $0.1 \cdots$ & 0.0 \\
\hline Abra tenuis & 0 & 0 & 0 & 0.0 & 0.0 & 0.0 \\
\hline Carcinus maenas & 2 & 2 & 3 & 0.1 & 0.4 & 0.1 \\
\hline Crangon crangon + & 6 & $7^{*}$ & 10 & 0.1 & 0.4 & 0.1 \\
\hline \multicolumn{7}{|l|}{ Nospecific pattern } \\
\hline Mya arenaria & 2 & $1 \cdots$ & $143^{\cdots}$ & $4.1 \cdots$ & $0.8^{\cdots}$ & 8.0 \\
\hline Hydrobia ulvae & $10^{*}$ & $1800^{\circ}$ & $3260^{\circ}$ & 0.0 & 0.5 & $0.8^{*}$ \\
\hline Retusa alba & 0 & 0 & 0 & 0.0 & 0.0 & 0.0 \\
\hline Gammarus spp. & 1 & 1 & 0 & 0.0 & 0.0 & 0.0 \\
\hline Corophium spp. & 17 & 25 & 18 & 0.0 & 0.0 & 0.0 \\
\hline Bathyporeia spp. & 2 & 4 & 16 & 0.0 & 0.0 & 0.0 \\
\hline other species & 18 & 18 & 32 & 0.0 & $0.1^{\cdots}$ & $1.1^{\cdots}$ \\
\hline Totals & & & & 18.5 & $16.9^{*}$ & $38.5^{\cdots}$ \\
\hline
\end{tabular}


(1) In 8 out of the 11 increasing species the 1987-values for both numerical density and biomass were significantly higher than in 1977 or 1971-72. Among the remaining 3 species, 2 were so scarce on these tidal flats that their changes could not be evaluated (Table 1).

(2) The total biomass in 1987 was not only significantly higher than in 1977 or 1971-72 ( $\mathrm{p}<0.01$, Wilcoxon's test with $\mathrm{n}=26)$, but also closely matched the mean values found at Balgzand in each of the 3 years of observation (Fig. 2a). At 24 out of the 26 stations the biomass observed in 1987 was higher than in 1977 and at 22 stations higher than in 1971-72.

(3) Total numbers of species were similar in the two areas (Fig. 2b); the (significant: $\mathrm{p}<0.01$ ) increase of mean number of species per station was even steeper on the other tidal flats than at Balgzand (Fig. 2c).

Thus, nearly all increasing trends observed in the restricted area of Balgzand were also found in the $\sim 10$ times larger area. It is not known whether these increases extend to other parts of the Wadden Sea. Essink (pers. comm.) did not observe a clear increase in total biomass during the same period in his sampling area (a few $\mathrm{km}^{2}$ with 5 stations) in the eastern part of the Dutch Wadden Sea. Only in Heteromastus filiformis have significant increases been reported for more eastern parts of the Wadden Sea (Groninger Wad: Essink, pers. comm.; Borkum: Obert, 1982; Norderney: Dörjes et al., 1986).

The increases of abundance in several species and in total biomass and production of the zoobenthos will have been caused by eutrophication, because primary production and algal stocks also doubled in the area during the same period (Cadée, 1986; Beukema \& Cadée, 1986).

\section{Fluctuations related to winter temperatures}

Among the 29 species studied at Balgzand, 12 proved to be sensitive to low winter temperatures (Table 1): they showed low abundance values immediately after severe winters (around March) and generally also low over-winter survival (or enhanced emigration) during cold winters (Beukema, 1979, 1985). On the other hand, their numbers were high after a series of mild winters in succession (Beukema et al., 1978). Examples of the resulting fluctuation patterns are shown in Figure 3. Note the (almost) complete absence of some species at the end of the extremely cold winter of 1979 , and the high numbers in 1975 after 3 mild winters in succession (Fig. 3b).

After a severe winter, values for total biomass tended to be lower than after preceding or subsequent mild winters (Fig. 2a), but the differences were not great (for reasons explained in Beukema, 1979). Species numbers were also relatively low after cold winters (Fig. 2b and 2c) owing to the (nearly) complete absence of the most sensitive species.

Winter-related fluctuation patterns closely resembled each other over vast areas. Figure 3c shows an example of Nephtys hombergii densities at 3 Balgzand stations a few $\mathrm{km}$ apart; an almost equally high correlation was observed between the mean density values for this species in two areas $\sim 150 \mathrm{~km}$ apart (Fig. 3d). Even on a tidal flat area $\sim 100 \mathrm{~km}$ further to the east ( $\sim 250 \mathrm{~km}$ from Balgzand), at Norderney, a similar fluctuation pattern was observed in this species (Rhode, 1986).

The coldest winters $(1979,1985,1986$, and 1987) during the 1969-1988 period occurred during the second half of the period of observation (Fig. 3a). This will have been 

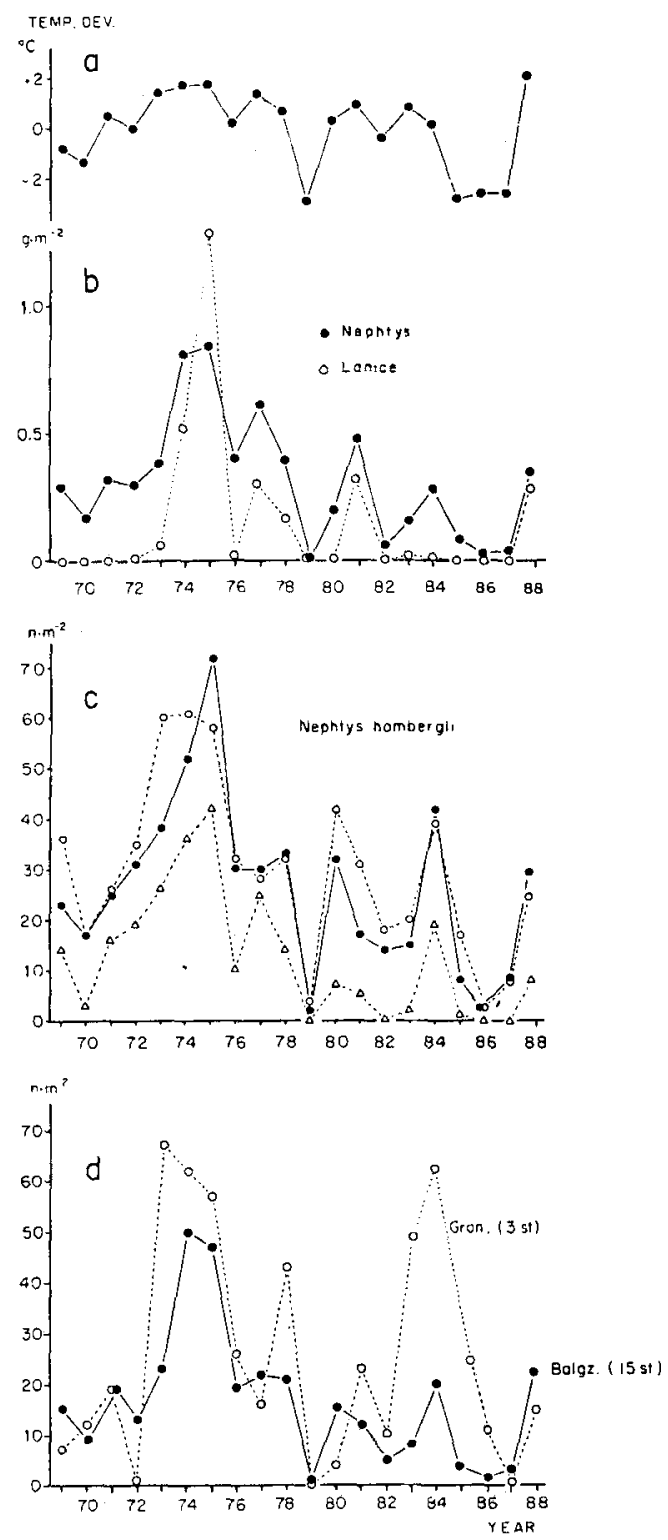

Fig. 3. Examples of fluctuation patterns during the 1969-1988 period, governed by winter temperatures. Balgzand data are means of $15(b, d)$ or single $(c)$ stations sampled anually in or around March. (a) Deviations of mean winter temperatures (as in Fig. 2d). (b) Mean biomass values (g AFDW per $\mathrm{m}^{2}$ ) of Nephtys hombergii (solid points, full lines) and Lanice conchilega (open points, broken lines). (c) Numerical densities $\left(\mathrm{n} \cdot \mathrm{m}^{-2}\right.$ ) of Nephtys hombergii at 3 individual Balgzand stations. (d) Mean densities $\left(\mathrm{n} \cdot \mathrm{m}^{-2}\right.$ ) of Nephtys hombergii in two tidal flat areas $\sim 150 \mathrm{~km}$ apart, viz. Balgzand (solid points, full lines) and Groninger Wad (open points, broken lines; amended from Beukema \& Essink, 1986; courtesy K. Essink). In all cases the correlations between the 7 patterns shown were highly significant ( $\mathrm{r}$ between +0.7 and +0.9 ) and so were the correlations between these patterns and winter temperatures 
the cause of the significantly decreasing trend observed in two sensitive species, viz. Angulus tenuis and Mysella bidentata. In another sensitive species, viz. Crangon crangon, the numbers in the samples taken in summer showed an increasing trend, whereas no clear trend was found in the March samples (Table 1).

Several species (bivalves in particular) show highly successful recruitment during the summer following a cold winter (Beukema, 1982). This positive effect of a severe winter will have been the cause of the high numbers observed in the autumn of 1987 in the bivalves Cerastoderma edule, Mya arenaria, and Macoma balthica all over the area sampled (Table 1).

As the samples at stations outside Balgzand were all taken in summer or autumn, most winter losses were restored by then and the winter-related fluctuation pattern will be reflected only partly in the data shown in Table 1. Significant differences between the densities over the 3 years were relatively scarce in the group of winter-sensitive species. The high densities of some sensitive species (viz. Angulus tenuis, Lanice conchilega and its commensal Harmothoe lunulata) observed in 1977 will have been caused by the character of the 5 preceding winters, which were all milder than average (Fig. 3a).

\section{Other patterns}

Finally, 6 out of the 29 species (which were studied in detail at Balgzand) showed neither a consistent increase nor a winter-related pattern (bottom group in Table 1). Among this small group were 2 out of the 4 crustacean species and 2 out of the 3 gastropods. On the other hand, the large groups of polychaetes and bivalves were underrepresented in this group of "other patterns". In all or nearly all species of these large taxonomic groups the fluctuation pattern could be included in one of the two main types.

On the tidal flats beyond Balgzand, there were relatively few significant differences in mean densities of species belonging to the group of the 6 remaining species. Only Hydrobia ulvae showed a strong increase. Among the unnamed "other species" (which showed 0-numbers during most years at Balgzand), the high numbers of Urothoe spp. should be mentioned and the high biomass value observed in 1987 for Ensis directus, a recent immigrant from N. America (Essink, 1985).

\section{Local departures from general patterns}

Beukema \& Essink (1986) showed that fluctuation patterns in several tidal-flat species ran parallel at most stations. These fluctuations resembled each other the more closely the nearer the stations were to one another. Non-parallel fluctuation patterns were observed in a few species only and these could be explained by migrations between the two subareas with non-parallel fluctuations (within these subareas the fluctuations ran parallel).

Other examples of fluctuation patterns diverging distinctly from the general (common) patterns appear to be rare. Essink \& Beukema (1986) mention the case of a few sampling stations near a sewage discharge, whereas other nearby stations (at slightly longer distances from the discharge) showed the general fluctuation pattern (e.g. Fig. 3d: Groninger Wad). At Balgzand, some examples of aberrant density changes were 


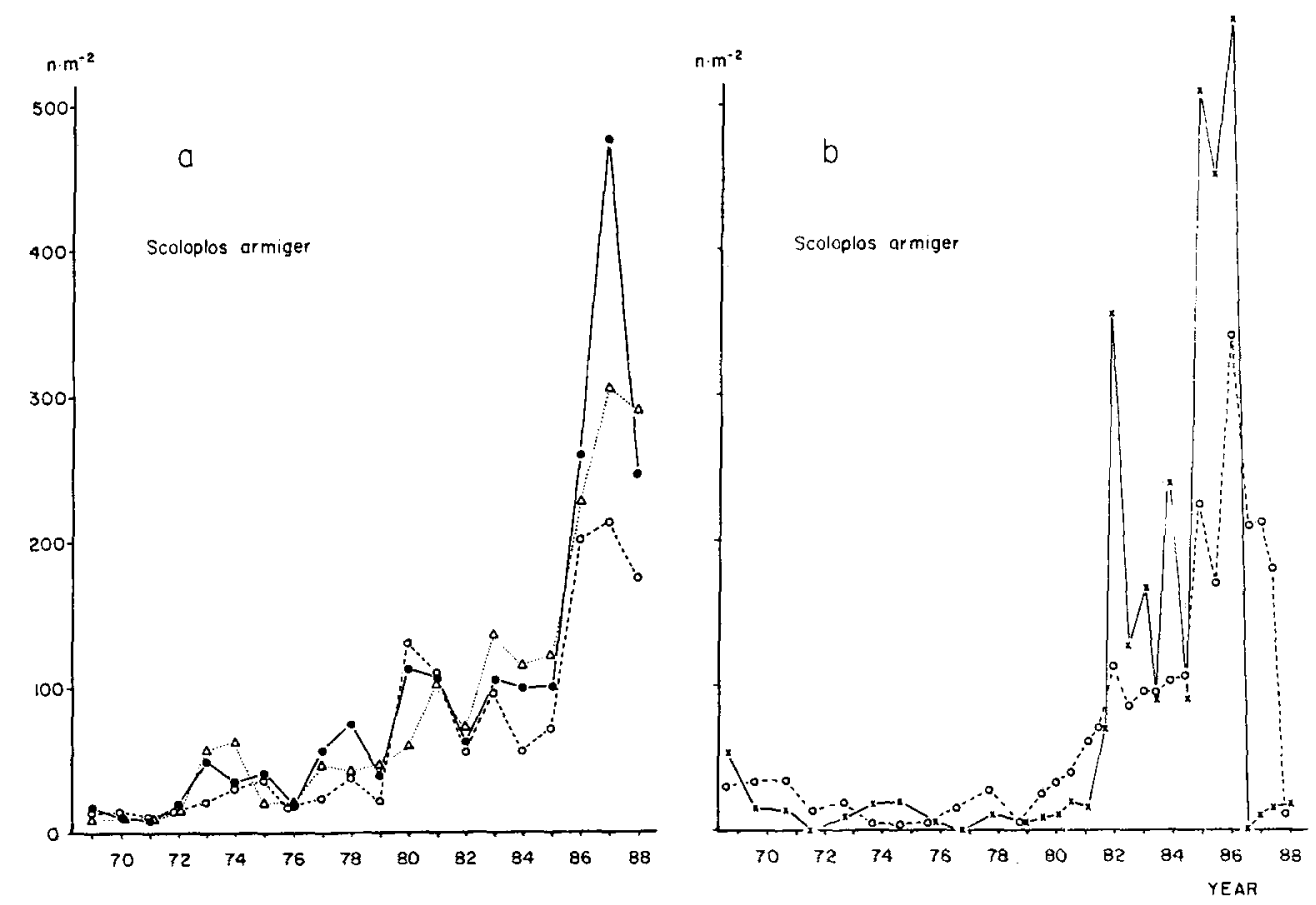

Fig. 4. Long-term changes in numerical densities $\left(\mathrm{n} \cdot \mathrm{m}^{-2}\right)$ of Scoloplos armiger at various Balgzand stations. Data from annual samples taken in or around March during 1969-1988 and from 1979 onwards also in August-September. (a) At 3 undisturbed stations. (b) At 2 stations where a disturbance took place, at one station in winter (solid line: early 1987) and at another in summer (broken line: mid 1988)

observed recently in the polychaete Scoloplos armiger (Fig. 4b). At nearly all stations, this species showed consistently increasing densities (Fig. 4a). However, at one station (solid line in Fig. 4 b) all $S$. armiger suddenly disappeared during the winter of 1986-87. This station was located in an area with an unusually complete ice cover that rested upon the bottom for several weeks in early 1987. Dying specimens that had left the sediment could be seen in the few cracks of the ice field, pointing to suffocation as the cause of death. After the ice had melted, no living specimens were observed in an area of $\sim 1 \mathrm{~km}^{2}$ that had been covered completely by the ice. Apart from the 1 sampling station within this area, all other Balgzand stations with generally high $S$. armiger densities showed the normal high number of this species in March 1987 (Fig. 4a and interrupted line in Fig. $4 \mathrm{~b}$ ).

In a few species (viz. S. armiger and Nephtys hombergii), low survival was noted also during the summer of 1988 at a few adjacent stations (e.g. interrupted line in Fig. 4b), whereas their numbers remained rather high at the other 5 or 6 stations where these species were abundant. Again, low oxygen concentrations were probably the cause of the local disappearance of these species. Oxygen concentrations are relatively low in summer at Balgzand (Tijssen \& van Bennekom, 1976) and may occasionally drop to 0 during the night (Van der Veer \& Bergman, 1986). The summer of 1988 showed 
prevailing cloudy weather and an extremely low number of sunny hours in the Netherlands. Oxygen production thus may have been low and oxygen consumption relatively high during the relatively warm nights. The increasing eutrophication, with high densities of the flagellate Phaeocystis pouchetii (Cadée \& Hegeman, 1986), may have been decisive. In 1988, the bloom of this species persisted for an exceptionally long period (Cadée, pers. comm.).

The stations where low survival was observed in the summer of 1988 were situated near the local water shed, where mixing with oxygen-rich water from the North Sea will be relatively slight. The two species involved show maximal densities in relatively clean and well-oxygenated sands (Dankers \& Beukema, 1983). S. armiger appears to be poorly adapted to low oxygen concentrations (Schöttler \& Grieshaber, 1988).

\section{CONCLUSIONS}

Parallel fluctuations in population densities are an existing phenomenon occurring both within species in different areas and within areas in different species. By far the major part of the macrozoobenthic species living at Balgzand were found to follow one of the two predominant fluctuation patterns: either an increasing trend or a characteristic temperature-governed pattern. The latter pattern was found to occur all over the Dutch Wadden Sea, the former pattern may be limited to the western half of this area. Climatic factors such as severe winters act over vast areas; eutrophication may have been serious only in the western part of the Wadden Sea, because the influence of the discharge of the river Rhine is stronger in that area, both by direct transport of fresh water along the Dutch mainland coast and via Lake IJssel.

Significant deviations from the general patterns were identified in 3 cases. All were of a strictly local character. One was associated with a waste discharge (Essink \& Beukema, 1986), the other two concerned local suffocation in one or two species apparently sensitive to lack of oxygen. These two cases surely would have passed undetected without an adequate monitoring programme. If they had nevertheless been detected, the infrequent occurrence and the local nature of these die-outs would have been unknown.

The present monitoring programme for zoobenthos in the western part of the Wadden Sea appears appropriate. The programme will be continued by twice-annual sampling at the 15 permanent stations at Balgzand and occasional sampling at the 26 transects in other parts of the western half of the Dutch Wadden Sea.

It would be desirable that comparable programmes were executed in areas in other parts of the Wadden Sea. These areas should be large enough to cover a wide range of intertidal levels and sediment types. Permanent stations (marked by iron poles) should be established. Such stations should preferably be long transects instead of small plots because of the nature of the distribution types of most species (often in clusters of a size up to some hundreds of meters, see Beukema et al., 1983). About 5 varied sampling areas containing $\sim 10$ transects each and located $\sim 100 \mathrm{~km}$ apart would adequately describe changes in the macrozoobenthos caused by climatic effects and detect local deviations from general patterns caused by e.g. human disturbance. The COST-647 programme would provide an existing frame work for such an internationally coordinated programme. 


\section{LITERATURE CITED}

Beukema, J. J., 1974. Seasonal changes in the biomass of the macrobenthos of a tidal flat area in the Dutch Wadden Sea. - Neth. J. Sea Res. 8, 94-107.

Beukema, J. J., 1979. Biomass and species richness of the macrobenthic animals living on a tidal flat area in the Dutch Wadden Sea: effects of a severe winter. - Neth. J. Sea Res. 13, 203-223.

Beukema, J. J., 1982. Annual variation in reproductive success and biomass of the major macrozoobenthic species living in a tidal flat area of the Wadden Sea. - Neth. J. Sea Res. 16, 37-45.

Beukema, J. J., 1985. Zoobenthos survival during severe winters on high and low tidal flats in the Dutch Wadden Sea. In: Marine biology of polar regions and effects of stress on marine organisms. Ed. by J. S. Gray \& M. E. Christiansen. Wiley, Chichester, 351-361.

Beukema, J. J., 1988. An evaluation of the ABC-method (abundance/biomass comparison) as applied to macrozoobenthic communities living on tidal flats in the Dutch Wadden Sea. - Mar. Biol. 99, 425-433.

Beukema, J. J. \& Cadée, G. C., 1986. Zoobenthos responses to eutrophication of the Dutch Wadden Sea. - Ophelia $26,55-64$.

Beukema, J. J. \& Essink, K., 1986. Common patterns in the fluctuations of macrozoobenthic species living at different places on tidal flats in the Wadden Sea. - Hydrobiologia 142, 199-207.

Beukema, J. J., Bruin, W. de, Jansen, J. J. M., 1978. Biomass and species richness of the macrobenthic animals living on the tidal flats of the Dutch Wadden Sea: long-term changes during a period with mild winters. - Neth. J. Sea Res. 12, 58-77.

Beukema, J. J., Cadée, G. C. \& Hummel, H., 1983. Differential variability in time and space of numbers in suspension and deposit feeding benthic species in a tidal flat area. - Oceanol. Acta, Vol. spéc., 21-26.

Brinch Madsen, P., 1984. The dynamics of the dominating macrozoobenthos in the Danish Wadden Sea 1980-1983, - Rep. mar. Pollut. Lab. Charlottenlund 7, 1-35.

Cadée, G. C., 1986. Increased phytoplankton primary production in the Marsdiep area (western Dutch Wadden Sea). - Neth. J. Sea Res. 20, 285-290.

Cadée, G. C. \& Hegeman, J., 1986. Seasonal and annual variation in Phaeocystis pouchetii (Haptophyceae) in the westernmost inlet of the Wadden Sea during the 1973 to 1985 period. - Neth. J. Sea Res. 20, 29-36.

Dankers, N. \& Beukema, J. J., 1983. Distributional patterns of macrozoobenthic species in relation to some environmental factors. In: Ecology of the Wadden Sea. Ed. by W. J. Wolff. Balkema, Rotterdam, 1 (4), 69-103.

Dörjes, J., Michaelis, H. \& Rhode, B., 1986. Long-term studies of macrozoobenthos in intertidal and shallow subtidal habitats near the island of Norderney (East Frisian coast, Germany). - Hydrobiologia 142, 217-232.

Essink, K., 1985, On the occurrence of the American jack-knife clam Ensis directus (Conrad, 1843) (Bivalvia, Cultellidae) in the Dutch Wadden Sea. - Basteria 49, 73-80.

Essink, K. \& Beukema, J. J., 1986. Long-term changes in tidal flat macrozoobenthos as an indicator of stress by organic pollution. - Hydrobiologia 142, 209-215.

Koninklijk Nederlands Meteorologisch Instituut (KNMI), 1968-1988. Maandoverzicht van het weer in Nederland (before 1981: Maandelijks overzicht der weersgesteldheid). KNMI, De Bilt, the Netherlands, 65-85.

Obert, B., 1982. Bodenfauna der Watten und Strände um Borkum-Emsmündung. - Jber. Forschst. Insel-Küstenschutz Norderney 33, 139-162.

Rhode, B., 1986. Langfristige Bestandsänderungen der makrobenthischen Fauna im Watt bei Norderney: non-dominante Arten. - Jber. Forschst. Küste 37, 147-174

Schöttler, U. \& Grieshaber, M., 1988. Adaptation of the polychaete worm Scoloplos armiger to hypoxic conditions. - Mar. Biol. 99, 215-222.

Tijssen, S. B. \& Bennekom, A. J. van, 1976. Lage zuurstofgehalten in het water op het Balgzand. $\mathrm{H}_{2} \mathrm{O} 9,28-31$.

Veer, H. W. van der \& Bergman, M. J. N., 1986. Development of tidally related behaviour of a 0 group plaice (Pleuronectes platessa L.) population in the western Wadden Sea. - Mar. Ecol. Prog. Ser. 31, 121-129. 